\title{
Synthesis, cytotoxicity, apoptosis and cell cycle arrest of a ruthenium multi-substituted Keggin-type polyoxotungstate
}

\section{Shifang Jia}

Taiyuan University of Science and Tecnology

\section{Yanzhen Wen}

Taiyuan University of Science and Tecnology

\section{Xiuli Hao}

Taiyuan University of Science and Tecnology

Yan Zhang ( $\triangle$ yanzhang872010@163.com )

Taiyuan University of Science and Tecnology

\section{Research Article}

Keywords: Ruthenium multi-substituted polyoxometalate, Cytotoxicity, Cell apoptosis, Cell cycle arrest

Posted Date: September 7th, 2021

DOI: https://doi.org/10.21203/rs.3.rs-863084/v1

License: (9) This work is licensed under a Creative Commons Attribution 4.0 International License. Read Full License 


\section{Abstract}

The ruthenium multi-substituted polyoxotungstate with chemical formulae of $\mathrm{K}_{7}\left[\mathrm{SiW}_{9} \mathrm{O}_{37} \mathrm{Ru}_{4}\left(\mathrm{H}_{2} \mathrm{O}\right)_{3} \mathrm{Cl}_{3}\right] \cdot 15 \mathrm{H}_{2} \mathrm{O}(\mathrm{S} 1)$ was synthesized by a conventional aqueous solution containing the trilacunary Keggin-anions $\beta-\mathrm{Na}_{9} \mathrm{HSiW}_{9} \mathrm{O}_{34} \cdot 12 \mathrm{H}_{2} \mathrm{O}(\mathrm{S} 2)$ and $\mathrm{RuCl}_{3} \cdot \mathrm{nH}_{2} \mathrm{O}(\mathrm{S} 3)$. Compound $\mathbf{S} 1$ was characterized by elemental analyses, EDS, TG analyses, IR, UV/Vis and XPS. The cytotoxic potential of compound S1 was tested on C33A, DLD-1, HepG-2 cancer cells and human normal embryonic lung fibroblasts cell MRC-5. The viability of the treated cells was evaluated by MTT assay. The mode of cell death was assessed by morphological study of DNA damage and apoptosis assays. Compound S1 induced cell death in a dose-dependent manner, and the mode of cell death was essentially apoptosis though necrosis was also noticed. Cell cycle analysis by flow cytometry indicated that compound S1 caused cell cycle arrest and accumulated cells in S phase.

\section{Introduction}

Cancer has become one of the serious public health problems which has threatened human health in the world. At present, chemotherapy has been an important means and approach for cancer treatment. Therefore, to find an effective and low-toxicity drug has become the priority in the chemotherapeutic treatment of tumors ${ }^{[1-3]}$. In clinical application and experimental exploration, most of the chemotherapeutic drugs mainly composed of synthetical compounds and adjuvant chemotherapeutic of natural substances or photochemicals. Among them, the synthetical compounds have many advantages, such as designability, controllability and predictability, which attractted wide attention from researchers. In recent years, it is worth noting that polyoxometalates (POMs) are intriguing biomedical agents due to their versatile bioactivity that endows antibacterial, antitumor, and antiviral function $s^{[4-7]}$. Compared with current drugs, the unique advantage of POMs lies in the fact that the composition, molecular structure and physiochemical properties are adjustable and can be easily synthesized from readily available precursors in a few synthetic steps ${ }^{[8-11]}$. More importantly, another advantage of POMs is that transition metals can be introduced into their structure to obtain transition metal-substituted POMs, such as mono, dis or tri-substituted polyanions ${ }^{[12-14]}$. The combination of transition metals and vacancy POMs changed the composition, charge and physicochemical properties of the original saturated POMs, which also showed certain advantages in biological activity ${ }^{[15,16]}$.

In addition, ruthenium compounds, owing to the low energy barrier between their oxidation states, low atomic radius $(0.125 \mathrm{~nm})$ in transition metal series, and high solubility in water, which is conducive to accumulation in cancer tissues, have potential value in the development of chemotherapeutic drugs ${ }^{[17}$, 18]. Therefore, the synergistic effect of ruthenium and vacancy POMs is expected to endow rutheniumsubstituted polyoxometalates (Ru-POMs) with high antitumor activity. At present, a multitude of Ru-POMs have been reported ${ }^{[19-27]}$. It is noteworthy that the antitumor activities of these compounds have been seldom reported. During our research on the exploration of Ru-POMs, the antitumor activities of a monoruthenium(II)-substituted Dawson polyoxotungstate have been investigated ${ }^{[28]}$. However, we also 
noticed that the majority of the syntheses of Ru-POMs have used the monolacunary Keggin $\left[\mathrm{XW}_{11} \mathrm{O}_{39}\right]^{\mathrm{n}-}$ $(\mathrm{X}=\mathrm{P}, \mathrm{Ge}$ and $\mathrm{Si})$ or Dawson-type $\left[\mathrm{P}_{2} \mathrm{~W}_{17} \mathrm{O}_{61}\right]^{10-}$ polyoxoanions as reagents/ligands for the coordination to ruthenium ${ }^{[19-25]}$. The compounds synthesized by other types of lacancy POMs and ruthenium were rarely reported.

Based on aforementioned considerations, we choose trilacunary POMs $\beta-\left[\mathrm{SiW}_{9} \mathrm{O}_{34}\right]^{10-}\left(\beta-\mathrm{SiW}_{9}\right)$ and $\mathrm{RuCl}_{3} \cdot \mathrm{nH}_{2} \mathrm{O}$ as raw materials, preparing a ruthenium multi-substituted polyoxometalates, $\mathrm{K}_{7}\left[\mathrm{SiW}_{9} \mathrm{O}_{37} \mathrm{Ru}_{4}\left(\mathrm{H}_{2} \mathrm{O}\right)_{3} \mathrm{Cl}_{3}\right] \cdot 15 \mathrm{H}_{2} \mathrm{O}$ (S1). Furthermore, the cytotoxicity of compound $\mathbf{S} 1$ in vitro was evaluated by MTT (3-(4,5-dimethylthiazol-2-yl)-2,5-diphenyltetrazolium bromide) assay. The morphological apoptosis and the percentage of necrotic and apoptotic C33A (human cervical cancer) cells induced by the complex were also studied by fluorescence microscopy and flow cytometry. The cell cycle distribution of C33A cells was investigated by flow cytometry. The results indicated that compound $\mathbf{S 1}$ could inhibit cell proliferation and induce apoptosis in cancer cells.

\section{Experimental}

\subsection{Materials and instrumentation}

All reagents and solvents were of commercial origin and were used without further purification unless otherwise noted. Ultrapure Milli-Q water was used in all experiments. $\beta-\mathrm{Na}_{9} \mathrm{HSiW}_{9} \mathrm{O}_{34} \cdot 12 \mathrm{H}_{2} \mathrm{O}$ was prepared according to the reported methods. ${ }^{[29]}$ RPMI 1640 was purchased from Sigma. C33A (human cervical cancer), DLD-1 (human colon cancer), HepG-2 (human liver cancer), MRC-5 (human normal embryonic lung fibroblasts) cell lines were purchased from the American Type Culture Collection. W, Ru and $\mathrm{K}$ were determined by a Leaman inductively coupled plasma (ICP) spectrometer. $\mathrm{Cl}$ was analyzed by ion chromatography. Energy-dispersive X-ray spectroscopy (EDS) was performed by X-Max Extreme. TG analyse was carried out on a Pyris Diamond TG instrument in flowing $\mathrm{N}_{2}$ with a heating rate of $10^{\circ} \mathrm{C} \cdot \mathrm{min}^{-}$

1. Infrared spectra was recorded on a Perkin-Elmer Spectrum FT-IR Spectrometer using KBr pellets. Raman spectrum was tested by the Raman spectrometer. Electronic absorption spectra (UV/Vis) was recorded on a Lambda750 spectrophotometer. X-ray photoelectron spectroscopy (XPS) of Ru and W were measured on a VG ESCALAB MK II spectrometer with a Mg Ka (1253.6 eV) achromatic X-ray source. Solution electronic emission spectra in acetonitrile was recorded on Shimadzu 3100 spectrophotometer and Shimadzu RF-5301 PC spectrofluorometer. Cyclic voltammetry (CV) was obtained with CHI 630E instrument in a three-electrode cell: glassy carbon electrode (GCE, diameter $3 \mathrm{~mm}$ ) as a working electrode, platinum wire as a counter electrode, and $\mathrm{Ag} / \mathrm{AgCl}$ as a reference electrode.

\subsection{Synthesis}

$\mathrm{K}_{7}\left[\mathrm{SiW}_{9} \mathrm{O}_{37} \mathrm{Ru}_{4}\left(\mathrm{H}_{2} \mathrm{O}\right)_{3} \mathrm{Cl}_{3}\right] \cdot 15 \mathrm{H}_{2} \mathrm{O}(\mathrm{S} 1)$

About $0.27 \mathrm{~g}$ of $\mathrm{RuCl}_{3} \cdot \mathrm{nH}_{2} \mathrm{O}(1.1 \mathrm{mmol})$ was dissolved in $8 \mathrm{ml}$ of water, and $1.00 \mathrm{~g}(0.37 \mathrm{mmol})$ of solid $\beta$ $\mathrm{Na}_{9} \mathrm{HSiW}_{9} \mathrm{O}_{34} \cdot 12 \mathrm{H}_{2} \mathrm{O}$ was added very slowly, with vigorous stirring at room temperature (addition should 
last about $1 \mathrm{~h})$. The $\mathrm{pH}$ was then adjusted to 5.5 with aqueous $\mathrm{Na}_{2} \mathrm{CO}_{3}(1 \mathrm{M})$, the resulting solution heated to $70-80{ }^{\circ} \mathrm{C}$ and stirred at this temperature for half an hour. After cooling, aqueous $\mathrm{Na}_{2} \mathrm{CO}_{3}$ was again added to adjust the $\mathrm{pH}$ 5.0, and the solution filtered to remove any solid impurities. The aqueous solution obtained was passed three times through an Amberlite cationic column (IR-120) in the $\mathrm{K}^{+}$form. $\mathrm{KCl}(1.0 \mathrm{~g}$, $13 \mathrm{mmol}$ ) was then added the resulting solution with stirring and black solids were precipitated immediately. The black solids were filtered after $24 \mathrm{~h}$. Anal. Calc.: W, 48.94; Ru, 11.94; K, 8.07; Cl, 3.15. Found: $\mathrm{W}, 49.75 ; \mathrm{Ru}, 12.25 ; \mathrm{K}, 8.19 ; \mathrm{Cl}, 3.09$. Molar ratio $\mathrm{W} / \mathrm{Ru}=2.23$.

\subsection{Methods}

\subsubsection{Cytotoxicity assay in vitro}

Standard MTT assay procedures were used ${ }^{[30]}$. Cells were placed in 96 -well microassay culture plates $\left(8 \times 10^{3}\right.$ cells per well) and grown overnight at $37^{\circ} \mathrm{C}$ in a $5 \% \mathrm{CO}_{2}$ incubator. The complex tested was then added to the wells to achieve final concentrations ranging from 2.5 to $100 \mu \mathrm{M}$. Control wells were prepared by addition of culture medium $(200 \mu \mathrm{L})$. The plates were incubated at $37^{\circ} \mathrm{C}$ in a $5 \% \mathrm{CO}_{2}$ incubator for $24 \llbracket 48$ or $72 \mathrm{~h}$. On completion of the incubation, stock MTT dye solution $(20 \mu \mathrm{L}, 5 \mathrm{mg} / \mathrm{mL})$ was added to each well. After $4 \mathrm{~h}, 150 \mathrm{~mL}$ dimethylsulfoxide (DMSO) was added to solubilize the MTT formazan. The optical density of each well was then measured with a microplate spectrophotometer at a wavelength of $490 \mathrm{~nm}$. The $\mathrm{IC}_{50}$ values were determined by plotting the percentage viability versus the concentration and reading off the concentration at which $50 \%$ of the cells remained viable relative to the control. Each experiment was repeated at least three times to obtain the mean values. Three different tumor cell lines were the subjects of this study: C33A, DLD-1 and HepG-2. And MRC-5 is the normal cell. These cells were purchased from the American Type Culture Collection (Rockville, MD, USA).

\subsubsection{Apoptosis assay by Hoechst 33342 staining}

C33A cells were seeded onto chamber slides in six-well plates at a density of $2 \times 10^{5}$ cells per well and incubated for $24 \mathrm{~h}$. The cells were cultured in RPMI 1640 supplemented with $10 \%$ fetal bovine serum (FBS) and incubated at $37^{\circ} \mathrm{C}$ and $5 \% \mathrm{CO}_{2}$. The medium was removed and replaced with medium (final DMSO concentration, $0.05 \% \mathrm{v} / \mathrm{v}$ ) containing the complex for $48 \mathrm{~h}$. The medium was removed, and the cells were washed with ice-cold phosphate-buffered saline(PBS), and fixed with formalin ( $4 \%, w / v)$. Cell nucleus were counterstained with Hoechst 33342 (10 mg/mL in PBS) for $10 \mathrm{~min}$. Then the cells were observed and imaged by a fluorescence microscope (Nikon, Yokohama, Japan) with excitation at $350 \mathrm{~nm}$ and emission at $460 \mathrm{~nm}$.

\subsubsection{Apoptosis assay by flow cytometry}

After chemical treatment, $2 \times 10^{5}$ cells were harvested, washed with PBS, then fixed with $70 \%$ ethanol, and finally, maintained at $4^{\circ} \mathrm{C}$ for at least $12 \mathrm{~h}$. Then the pellets were stained with the fluorescent probe solution containing $50 \mu \mathrm{g} / \mathrm{mL}$ propidium iodide and $1 \mathrm{mg} / \mathrm{mL}$ Annexin in PBS on ice in the dark for 15 
min. The fluorescence was then measured at 530 and $575 \mathrm{~nm}$ using 488-nm excitation by a FACS Calibur flow cytometry system. A minimum of 10,000 cells were analyzed per sample.

\subsubsection{Cell cycle arrest investigated by flow cytometry}

C33A cells were seeded into six-well plates at a density of $2 \times 10^{5}$ cells per well and incubated for $24 \mathrm{~h}$. The cells were cultured in RPMI 1640 supplemented with FBS (10\%) and were incubated at $37^{\circ} \mathrm{C}$ and $5 \%$ $\mathrm{CO}_{2}$. The medium was removed and replaced with medium (final DMSO concentration, $0.05 \% \mathrm{v} / \mathrm{v}$ ) containing complex. After incubation for $24 \mathrm{~h}$, the cell layer was trypsinized and washed with cold PBS and fixed with $70 \%$ ethanol. $20 \mu \mathrm{L}$ of RNase $(0.2 \mathrm{mg} / \mathrm{mL})$ and $20 \mu \mathrm{L}$ of propidium iodide $(0.02 \mathrm{mg} / \mathrm{mL})$ were added to the cell suspensions and they were incubated at $37^{\circ} \mathrm{C}$ for $30 \mathrm{~min}$. Then the samples were analyzed with a FACS Calibur flow cytometry system. The number of cells analyzed for each sample was 10,000 .

\section{Results And Discussion}

\subsection{Synthesis and characterization}

Compound $\mathbf{S 1}$ was obtained from solutions that were passed several times through an Amberlite cationic column in the potassium form, in order to eliminate the possibility of excessive non-coordinated Ru. This seems to indicate that Ru does not coprecipitate as counter-cation of the potassium salts of the polyoxoanions, but is included in the new formed complexes with the trilacunary species. In other words, this suggests that four ruthenium atoms must be coordinated to one $\mathrm{SiW}_{9}$ anion. According to the results of elemental analysis, the ratio of W/Ru in the compound S1 is 2.23, which proves the presence of four $\mathrm{Ru}$ atoms per $\mathrm{SiW}_{9}$ unit. Additionally, three chloride ions per $\mathrm{SiW}_{9}$ were found by analysis of ion chromatography. The existence of $\mathrm{W}, \mathrm{Ru}, \mathrm{K}, \mathrm{Cl}, \mathrm{O}$ was further confirmed by EDS (Fig. 1). The TG curve of compound S1 (Fig. 2) displays the weight loss of $9.66 \%$ in the temperature range of $30 \sim 325^{\circ} \mathrm{C}$, corresponding to three coordinated water molecules and fifteen lattice water molecules (calculated value 9.58\%). Based on analytical results and charge balance considerations, the molecular formula of compound $\mathrm{S} 1$ can be determined as $\mathrm{K}_{7}\left[\mathrm{SiW}_{9} \mathrm{O}_{37} \mathrm{Ru}_{4}\left(\mathrm{H}_{2} \mathrm{O}\right)_{3} \mathrm{Cl}_{3}\right] \cdot 15 \mathrm{H}_{2} \mathrm{O}^{[31]}$, which possibly possess construction being similar to that already observed for the Ni substituted polyoxometalate, $\left[\mathrm{PW}_{9} \mathrm{O}_{34} \mathrm{Ni}_{3}{ }_{3}(\mathrm{OH})_{3}\left(\mathrm{H}_{2} \mathrm{O}\right)_{3} \mathrm{Ni}\left(\mathrm{H}_{2} \mathrm{O}\right)_{3}\right]^{4-}\left(\mathrm{PW}_{9} \mathrm{Ni}_{4}\right)^{[32]}$ (Fig. 3).

The IR spectrum of compound S1 are shown in Fig. 4. In the spectrum, characteristic bands at $1002 \mathrm{~cm}^{-1}$, $955 \mathrm{~cm}^{-1}, 895 \mathrm{~cm}^{-1}$, and $782 \mathrm{~cm}^{-1}$ are attributed to $\mathrm{v}(\mathrm{Si}-\mathrm{O}), \mathrm{v}\left(\mathrm{W}-\mathrm{O}_{\mathrm{d}}\right)$ and $\mathrm{v}\left(\mathrm{W}-\mathrm{O}_{\mathrm{b} / \mathrm{c}}-\mathrm{W}\right)$, respectively ${ }^{[31]}$. The Raman spectrum of compound $\mathbf{S} 1$ showed fewer split bands: W-O $\mathrm{d}_{\mathrm{d}}\left(953 \mathrm{~cm}^{-1}\right), \mathrm{W}-\mathrm{O}_{\mathrm{b}}-\mathrm{W}\left(898 \mathrm{~cm}^{-1}\right)$ and $\mathrm{W}-\mathrm{O}_{\mathrm{c}}-\mathrm{W}\left(778 \mathrm{~cm}^{-1}\right)$ (Fig. 5). The consistency between Raman and IR spectrum confirmed the stability of the compound $\mathbf{S} 1$ in aqueous solution.

Electronic absorption spectra (UV/Vis) of compound S1 in aqueous solution showed a band of high intensity in the visible region, centred at about 435nm (Fig. 6), as observed for other Ru ${ }^{\text {III }}$ 
polyoxoanions ${ }^{[33-36]}$. X-ray photoelectron spectroscopy (XPS) was used to identify the W/Ru oxidation states. XPS spectra of W $4 \mathrm{f}$ in compound $\mathbf{S} 1$ shows two partially overlapped peaks which at 35.18 and $37.38 \mathrm{eV}$ are assigned to $4 \mathrm{f}^{7 / 2}$ and $4 \mathrm{f}^{5 / 2}$ of $\mathrm{W}(\mathrm{VI})$ center (Fig. 7a) ${ }^{[37]}$. The binding energy peaks at 282.38 and $286.48 \mathrm{eV}$ corresponds to $3 d^{5 / 2}$ and $3 d^{3 / 2}$ of the Ru(III) center (Fig. 7b) ${ }^{[31]}$.

\subsection{Luminescence spectra studies}

The solid-state fluorescent of S1 was studied by fluorescence spectrum. Compound $\mathbf{S} 1$ upon excitation onto their excitation maxima exhibited an emission band at $590 \mathrm{~nm}$. The emission profile and emission maxima was similar and independent of the excitation wavelength. The electronic emission spectral of compound $\mathbf{S} 1$ was presented in Fig. 8a. Moreover, solution-state fluorescent of compound S1 was also studied, the complex exhibited an emission band at $685 \mathrm{~nm}$ (Fig. 8b).

\subsection{Cyclic voltammetry}

The redox behavior of compound $\mathbf{S} 1$ has been investigated in $\mathrm{Na}_{2} \mathrm{SO}_{4}(0.5 \mathrm{M}) / \mathrm{H}_{2} \mathrm{SO}_{4}(1 \mathrm{M})$ solution with $\mathrm{pH}=3$ to complement the spectroscopic data. The investigation of electrochemical behavior was very useful to determine the extent of electronic interaction between the metal centers. The cyclic voltammogram of $\mathrm{RuCl}_{3} \cdot \mathrm{nH}_{2} \mathrm{O}$ showed no redox peak in the range of -0.5 to $1.0 \mathrm{~V}$. The cyclic voltammetry (CV) measurements of compound $\mathbf{S 1}$ with the scan rate of $50 \mathrm{mV} / \mathrm{s}$ were recorded in the potential range from +1000 to $-700 \mathrm{mV}$ in sulfate buffers with $\mathrm{pH}=3$ (Fig. 9). As shown in Fig. 9, the mean peak potentials $\left(E_{1 / 2}=\left(E_{c p}+E_{a p}\right) / 2\right)$ for l-l' of reversible redox peaks are $300 \mathrm{mV}$, which was assignable to the $\mathrm{Ru}^{\text {III/II }}$ couple ${ }^{[38]}$.

\subsection{Cytotoxicity assay in vitro}

The cytotoxicity of the $\mathbf{S 1}, \mathbf{S} 2$ and $\mathbf{S} 3$ was studied in C33A, DLD-1, HepG-2 and MRC-5 cell lines by means of the MTT cell survival assay. C33A, DLD-1, HepG-2 and MRC-5 cells were treated with different concentrations of complexes $\mathbf{S 1 - 3}$ for $24 \llbracket 48$ and $72 \mathrm{~h}$. For $24 \mathrm{~h}$ (Fig. 10a), the complexes showed the weak activity to the three cell lines with $\mathrm{IC}_{50}$ values were $74.06 \mu \mathrm{M}$ for C33A, $89.05 \mu \mathrm{M}$ for DLD-1 and more than $100 \mu \mathrm{M}$ for HepG2 of $\mathbf{S} 1$. The $\mathrm{IC}_{50}$ values of $\mathbf{S} 2$ and $\mathbf{S} 3$ to three cell lines were more than $100 \mu \mathrm{M}$. For $48 \mathrm{~h}$ (Fig. 10b), the $\mathbf{S} 1$ showed the weak activity in the C33A and DLD-1 with IC $_{50}$ values of 75.72 and $89.73 \mu \mathrm{M}$, respectively, and $\mathrm{IC}_{50}$ values of more than $100 \mu \mathrm{M}$ for HepG2. However, S2 and S3 showed the weak activity to the three cell lines with $\mathrm{IC}_{50}$ values were nearly $100 \mu \mathrm{M}$. For $72 \mathrm{~h}$ (Fig. 10c), the $\mathrm{IC}_{50}$ of the $\mathbf{S} 1$ was $45.48 \mu \mathrm{M}$ for $\mathrm{C} 33 \mathrm{~A}, 78.32 \mu \mathrm{M}$ for DLD-1 and $95.08 \mu \mathrm{M}$ for HepG-2. It is worth noting that the complexes have no cytotoxicity to the normal cell MRC-5 in different time, the $\mathrm{IC}_{50}$ values were more than $100 \mu \mathrm{M}$. The IC $\mathrm{C}_{50}$ of S1-3 to C33A, DLD-1 and HepG-2 in different time were displayed in Table 
1. Cytotoxicity of some Keggin and lacunary-Keggin sandwiched polyoxotungstates towards MadinDarby canine kidney (MDCK), Vero, HEp-2, and MT-4 cells was investigated by using MTT. All the compounds did not show any toxicity at concentrations of $<200 \mu \mathrm{M}$ for MDCK, Vero, and HEp-2 cells ${ }^{[39]}$. All of these comparisons led to the conclusion that the complexes we studied had greater antitumor activity than reported. Obviously, the cell viability was found to be concentration-dependent and durationdependent, which indicated that the $\mathbf{S} \mathbf{1}$ entered the cells slowly and killed the cells gradually. During three cell lines, $\mathbf{S} 1$ showed the highest activity to C33A, secondly DLD-1, finally HepG2.

Table 1

$\mathrm{IC}_{50}$ values of complexes against human tumor cell lines

\begin{tabular}{|c|c|c|c|c|}
\hline \multirow[t]{2}{*}{ Time } & \multirow[t]{2}{*}{ Complexes } & \multicolumn{3}{|l|}{$\mathrm{IC}_{50}(\mu \mathrm{M})$} \\
\hline & & C33A & DLD-1 & HepG-2 \\
\hline \multirow[t]{3}{*}{$24 \mathrm{~h}$} & s1 & $74.06 \pm 1.32$ & $89.05 \pm 1.75$ & $>100$ \\
\hline & S2 & $>100$ & $95.08 \pm 2.72$ & $>100$ \\
\hline & S3 & $>100$ & $>100$ & $>100$ \\
\hline \multirow[t]{3}{*}{$48 \mathrm{~h}$} & s1 & $75.72 \pm 2.52$ & $89.73 \pm 0.42$ & $>100$ \\
\hline & S2 & $91.25 \pm 0.98$ & $>100$ & $>100$ \\
\hline & S3 & $90.42 \pm 1.53$ & $89.59 \pm 1.93$ & $>100$ \\
\hline \multirow[t]{3}{*}{$72 \mathrm{~h}$} & s1 & $45.48 \pm 1.22$ & $78.32 \pm 1.48$ & $95.08 \pm 1.66$ \\
\hline & S2 & $87.25 \pm 0.35$ & $90.51 \pm 0.37$ & $>100$ \\
\hline & S3 & $85.47 \pm 1.76$ & $80.12 \pm 2.62$ & $>100$ \\
\hline
\end{tabular}

\subsection{Apoptosis studies by Hoechst 33342 staining and flow cytometry}

Hoechst 33342, which stains the cell nucleus, is a membrane permeable dye with blue fluorescence. Live cells with uniformly light blue nuclei were observed under fluorescence microscope after treatment with Hoechst 33342, while apoptotic cells had bright blue nuclei on account of karyopyknosis and chromatin

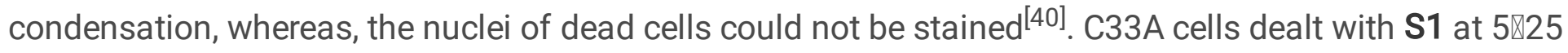
and $50 \mu \mathrm{M}$ for $48 \mathrm{~h}$ were stained with Hoechst 33342. C33A cells without dealing with the $\mathbf{S 1}$ was used as control. The results were given in Fig. 11. In the control, cells show homogeneous nuclear staining. After treatment of C33A cells with S1, the number of apoptotic cells increases in a dose-dependent manner and they exhibit typical apoptotic features, such as staining brightly, condensed chromatin, and fragmented nuclei. These results show the $\mathbf{S} 1$ can effectively induce the apoptosis against C33A cells. 
The morphological apoptosis studies showed $\mathbf{S} 1$ can induce apoptosis of C33A cells. To determine the percentages of apoptotic and necrotic cells, C33A cells without dealing with the $\mathbf{S} \mathbf{1}$ was used as control, apoptosis was investigated by flow cytometry, as shown in Fig. 12 In the control, the proportions of living cells and apoptotic cells were 99.6 and $0.3 \%$, respectively. After C33A cells have been exposed to S1 (5区 $25 \varangle 50 \mu \mathrm{M})$ for $48 \mathrm{~h}$, the proportions of apoptotic cells were $3.6,11.6$ and $54.5 \%$, respectively. Comparing with the control, the proportion of living cells decreased and apoptotic cells increased. These data demonstrate that the apoptotic effect on C33A cells for $\mathbf{S} \mathbf{1}$ is concentration-dependent, with increasing concentrations of $\mathbf{S} 1$, the number of apoptotic cells increases.

\subsection{Cell cycle arrest}

The distribution of C33A cells in various compartments during the cell cycle was analyzed by flow cytometry in cells stained with propidium iodide. As shown in Fig. 13, treatment of C33A cells with 5区25区 $50 \mu \mathrm{M} \mathrm{S1}$ for $48 \mathrm{~h}$ cause significant enhancement of $2.5,7.9$ and $16.5 \%$ in S phase compared with the control, treatment of C33A cells with $50 \mu \mathrm{M} \mathrm{S1}$ for $48 \mathrm{~h}$ cause decrease of $20.5 \mathrm{in} \mathrm{G}_{0} / \mathrm{G}_{1}$ phase compared with the control. These data show that $\mathbf{S} 1$ induce S-phase arrest in C33A cells ${ }^{[41]}$.

\section{Conclusions}

In summary, the introduction of ruthenium into the trilacunary POMs reaction system obtains a ruthenium multi-substituted polyoxometalates. In vitro, compound $\mathbf{S} 1$ exhibits higher cytotoxicity toward C33A than DLD-1 and HepG-2 cell lines under identical conditions. Hoechst 33342 staining demonstrated that compound $\mathbf{S} 1$ can effectively induce apoptosis of C33A cells. Apoptosis assay by flow cytometry showed the number of apoptotic cells increased with increasing concentration of compound $\mathbf{S 1}$. The cell cycle arrest studies demonstrated that the antiproliferative effect induced by compound S1 on C33A cells occurs in $\mathrm{S}$ phase. Thus, ruthenium-substituted polyoxometalates can be used as new potential candidate for chemotherapy drugs in the field of tumor chemotherapy. However, the possible mechanism of compound $\mathbf{S} 1$ on apoptotic induction in cancer cells needs to be further studied. This work is ongoing in our group.

\section{Declarations}

\section{Acknowledgements}

This work was supported by the National Natural Science Foundation of China (No. 21701120) and the Science and Technology Innovation Project of Colleges and Universities in Shanxi Province (No. 2020L0334). 
Competing interests: The authors declare no competing interests.

\section{References}

1. Huang X, Zhang Z, Jia L, Zhao Y, Zhang X, Wu K. Cancer. Lett., 2010,296:123-131

2. Liu H K, Wang Q, Li Y, Sun W G, Liu J R, Yang Y M, Xu W L, Sun X R, Chen B Q. J. Nutr. Biochem., 2010,21:206-213

3. Ghobrial I M, Witzig T E, Adjei A A. CA Cancer J. Clin., 2005,55:178-194

4. Hasenknopf B. Front. Biosci. Landmark Ed., 2005,10:275-287

5. Li H, Gong H W, Qi Y F, Li J, Ji X F, Sun J H, Tian R, Bao H, Song X F, Chen Q, Liu G L. Scientific Reports., 2017,7:16942-16950

6. Gerth H U V, Rompel A, Krebs B, Boos J, Lanvers-Kaminsky C. Anti-Cancer Drugs., 2005,16:101-106

7. Wang J, Liu Y, Xu K, Qi Y F, Zhong J, Zhang K, Li J, Wang E B, Wu Z Y, Kang Z H. Appl. Mater. Interfaces., 2014,6:9785-9789

8. Herve M, Sinoussi-Barre F, Chermann J, Hervé G, Jasmin C. Biochem. Biophys. Res. Commun., 1983,116:222-229

9. Aureliano M, Gândara R M, J. Inorg. Biochem., 2005,99:979-985

10. Lee I S, Long J R, Prusiner S B, Safar J G, J. Am. Chem. Soc., 2005,127:13802-13803

11. Müller C E, Iqbal J, Baqi Y, Zimmermann H, Röllich A, Stephan H. Bioorg. Med. Chem. Lett., 2006,16:5943-5947

12. Balula, S S, Santos I C M S, Barbosa A D S, Schlindwein W, Cavaleiro A M V, De Castro B, Cunha-Silva L. Materials Science Forum., 2013,730:975-980

13. Kikukawa Y, Suzuki K, Yamaguchi K, Mizuno N. Inorg. Chem., 2013,52:8644-8652

14. Dutta D, Jana A D, Debnath M, Mostafa G, Clérac R, Tojal J G, Ali M. Eur. J. Inorg. Chem., 2010,55175522

15. Wang L, Zhou B B, Yu K, Su Z H, Gao S, Chu L L, Liu J R, Yang G Y. Inorg. Chem., 2013,52:5119-5127

16. Wang L, Yu K, Zhou B B, Su Z H, Gao S, Chu L L, Liu J R. Dalton Trans., 2014,43:6070-6078

17. Sava G, Bergamo A, Int. J. Oncol., 2000,17:353-365

18. Rademaker-Lakhai J M, van den Bongard D, Pluim D, Beijnen J H, Schellens J H. Clinical cancer research: an official journal of the American Association for Cancer Research, 2004,10:3717-3727

19. Sadakane M, Tsukuma D, Dickman M H, Bassil B S, Kortz U, Capron M, Ueda W. Dalton Trans., $2007,2833-2838$

20. Yokoyama A, Ohkubo K, Ishizuka T, Kojima T, Fukuzumi S. Dalton Trans., 2012,41:10006-10013

21. Lahootun V, Besson C, Villanneau R, Villain F, Chamoreau L, Boubekeur K, Blanchard S, Thouvenot R, Proust A. J. Am. Chem Soc., 2007,129:7127-7135

22. Liu B, Yan J, Wang Y F, Yi X Y. Dalton Trans., 2015,44:16882-16887 
23. Liu H, Yue B, Sun W, Chen Z, Jin S, Deng J, Xie G, Shao Q, Wu T. Trans. Met. Chem., 1997,22:321-325

24. Nomiya K, Torii H, Nomura K, Sato Y. J. Chem. Soc. Dalton Trans., 2001,1506-1512

25. Ogo S, Shimizu N, Ozeki T, Kobayashi Y, Ide Y, SanoT J, Sadakane M. Dalton Trans., 2013,42:25402545

26. Howells A R, Sankarraj A, Shannon C. J. Am. Chem. Soc., 2004,126:12258-12259

27. Morris A M, Anderson O P, Finke R G. Inorg. Chem., 2009,48: 4411-4420

28. Jia S F, Hao X L, Wen Y Z, Zhang Y. Journal of Coordinationg Chemistry., 2019,72:633-644

29. Tézé A, Hervé G. Inorg. Synth., 1990,27:88

30. T. Mosmann, J. Immunol. Med., 1983,65:55-63

31. Gamelas J A F, Carapuca H M, Balula M S, Evtuguin D V, Schlindwein W, Figueiras F G, Amaral V S, Cavaleiro A M V. Polyhedron, 2010,29:3066-3073

32. Kortz U, Tézé A, Hervé G. Inorg. Chem., 1999,38:2038-2042

33. Neumann R, Abu-Gnim C. J. Am. Chem. Soc., 1990,112:6025-6031

34. Sadakane M, Higashijim M. Dalton Trans., 2003,659-664

35. Neumann R, Khenkin A M, Dahan M. Angew. Chem., Int. Ed., 1995,34:1587-1589

36. Quinonero D, Wang Y, Morokuma K, Khavrutskii L A, Botar B, Geletii Y V, Hill C L, Musaev D G. J. Phys. Chem. B., 2006,110:170-173

37. Hao X L, Ma Y Y, Wang Y H, Xu L Y, Liu F C, Zhang M M, Li Y G. Chem. Asian J., 2014,9:819-829

38. Landsmann S, Wessig M, Schmid M, Cölfen H, and Polarz S. Angew. Chem. Int. Ed., 2012,51:59955999

39. Yamase T. J. Mater. Chem., 2005,15:4773-4782

40. Li J F, Huang R Z, Yao G Y, Ye M Y, Wang H S, Pan Y M, Xiao J T. Eur. J. Med. Chem., 2014,86:175188

41. Zhang Y, Hu P C, Cai P, Yang F, Cheng G. Z. RSC Adv., 2015,5:11591-11598

\section{Figures}




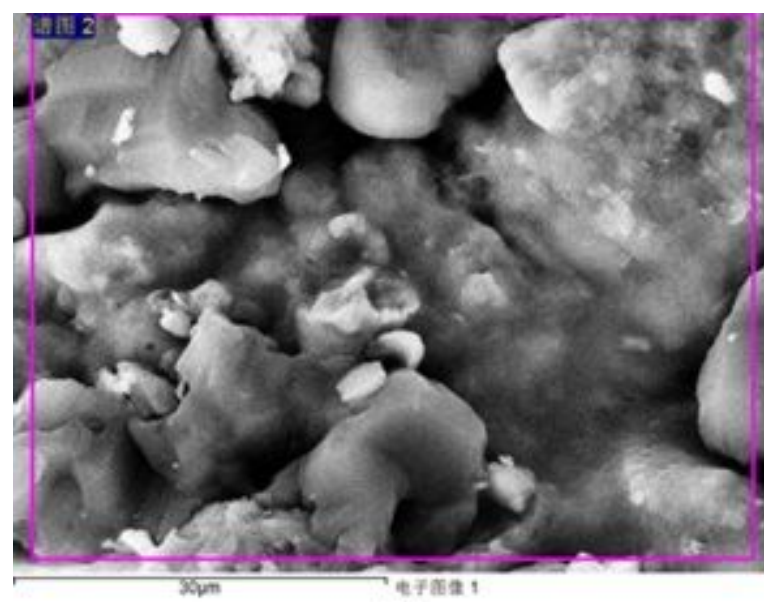

(a)

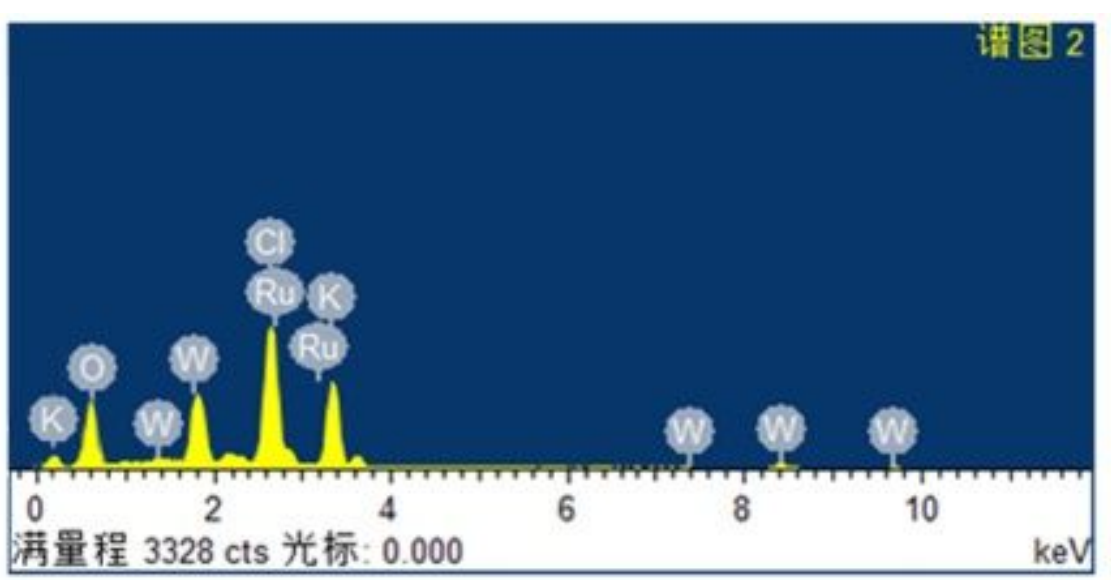

(b)

Figure 1

(a) SEM image of compound S1; (b) EDS of compound S1

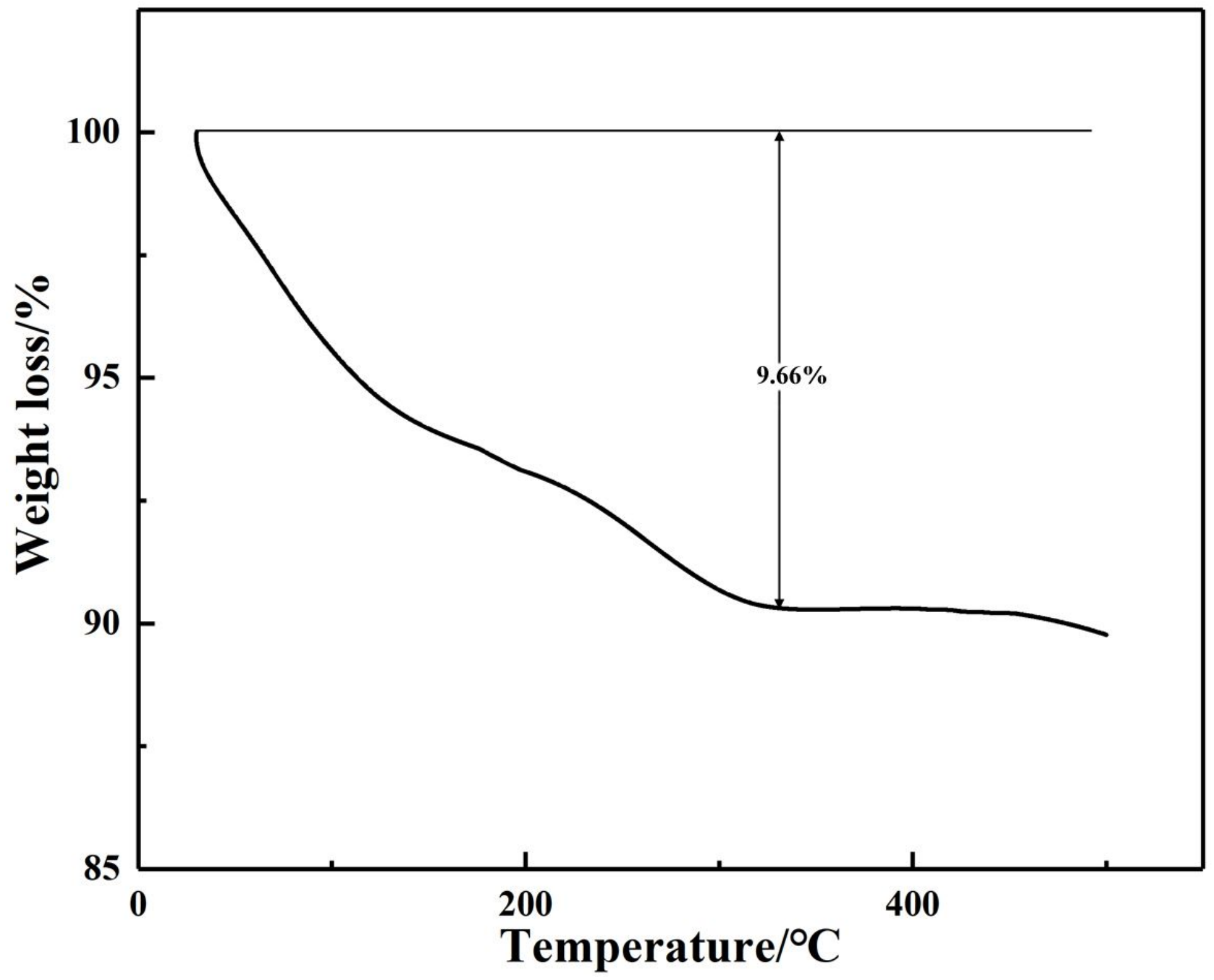


Figure 2

TG curve of compound S1

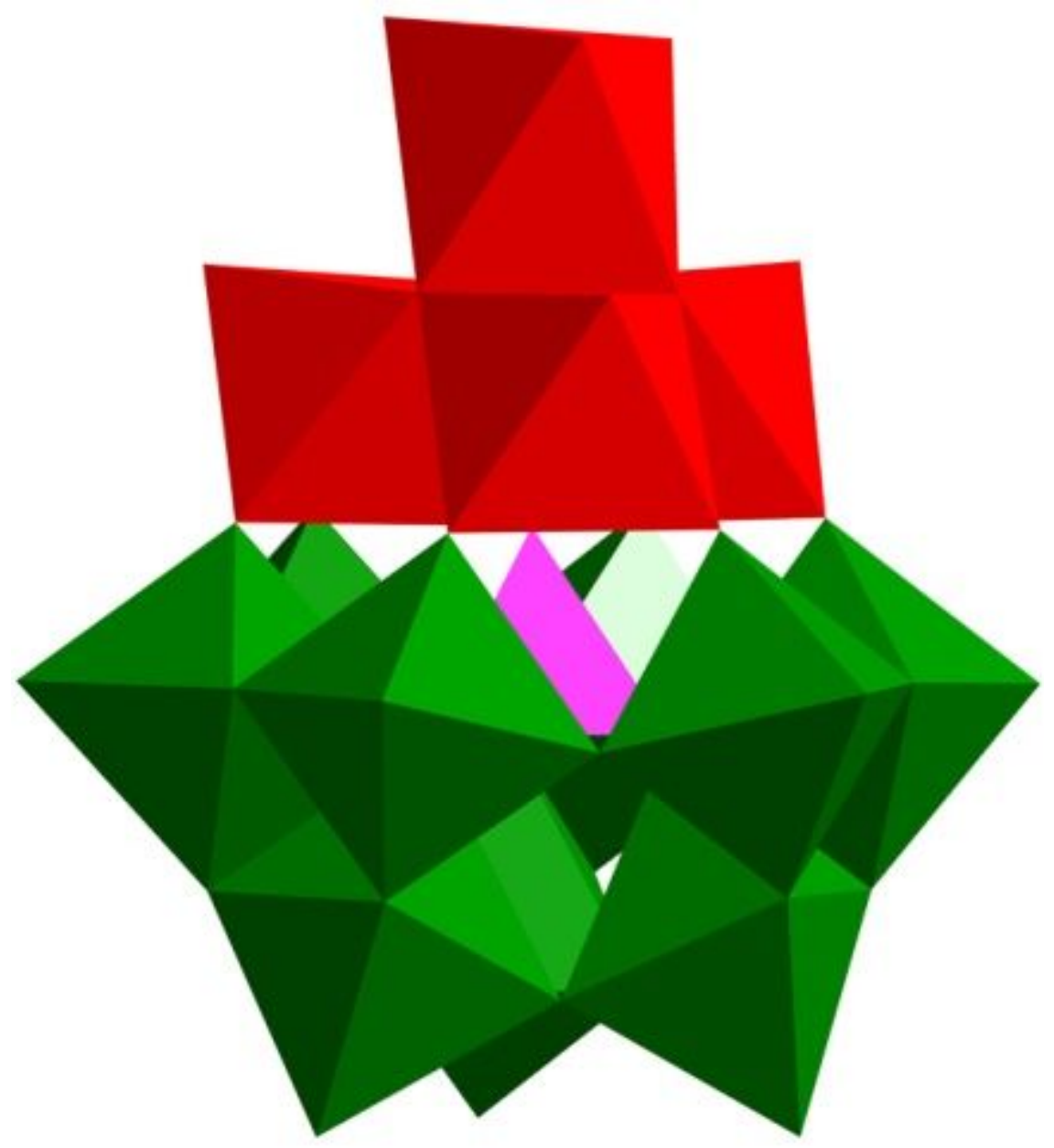

Figure 3

Possible structure for the Ru tetra-substituted anions [SiW9037Ru4(H2O)3Cl3]7- in compounds S1 


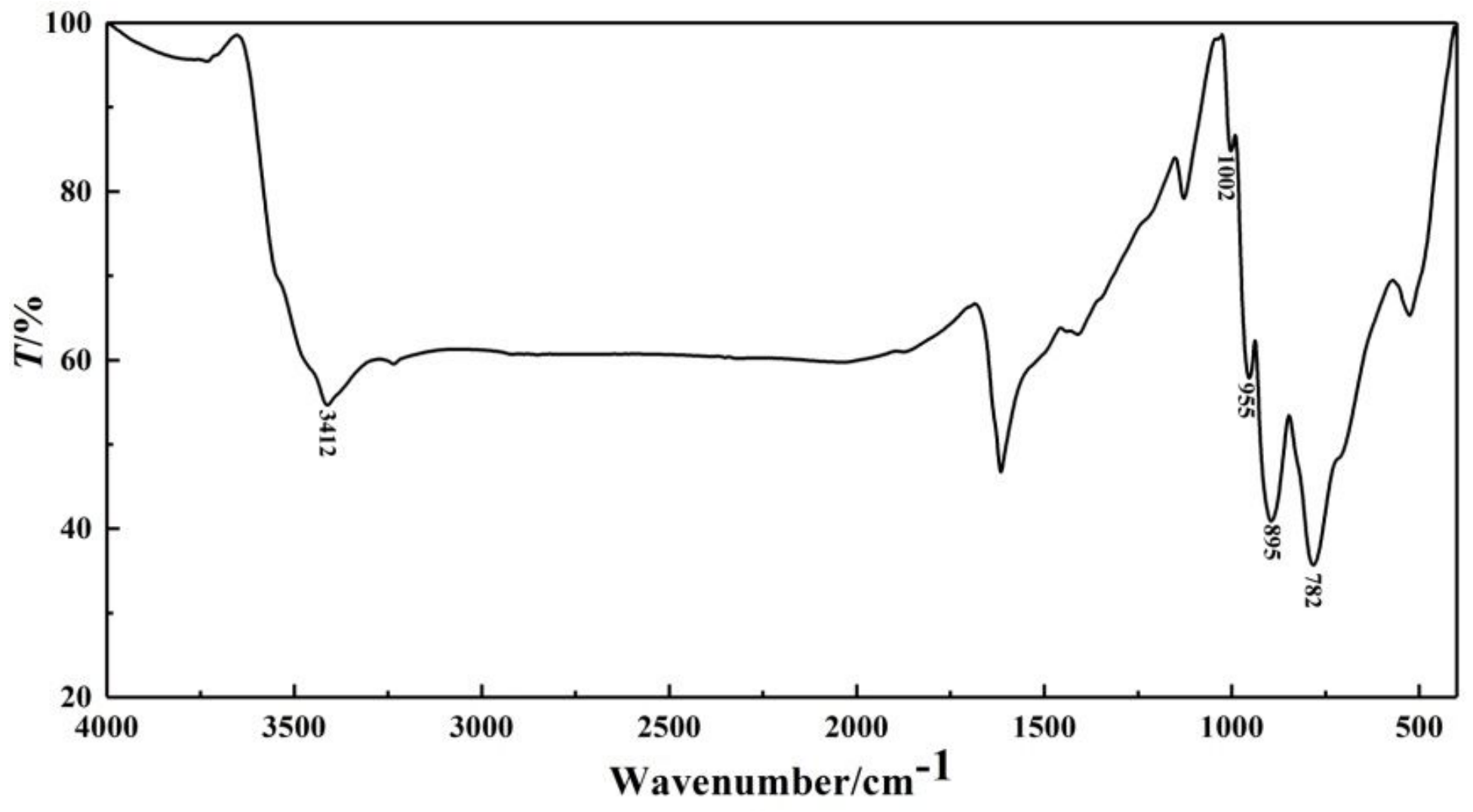

Figure 4

IR spectrum of compound S1 


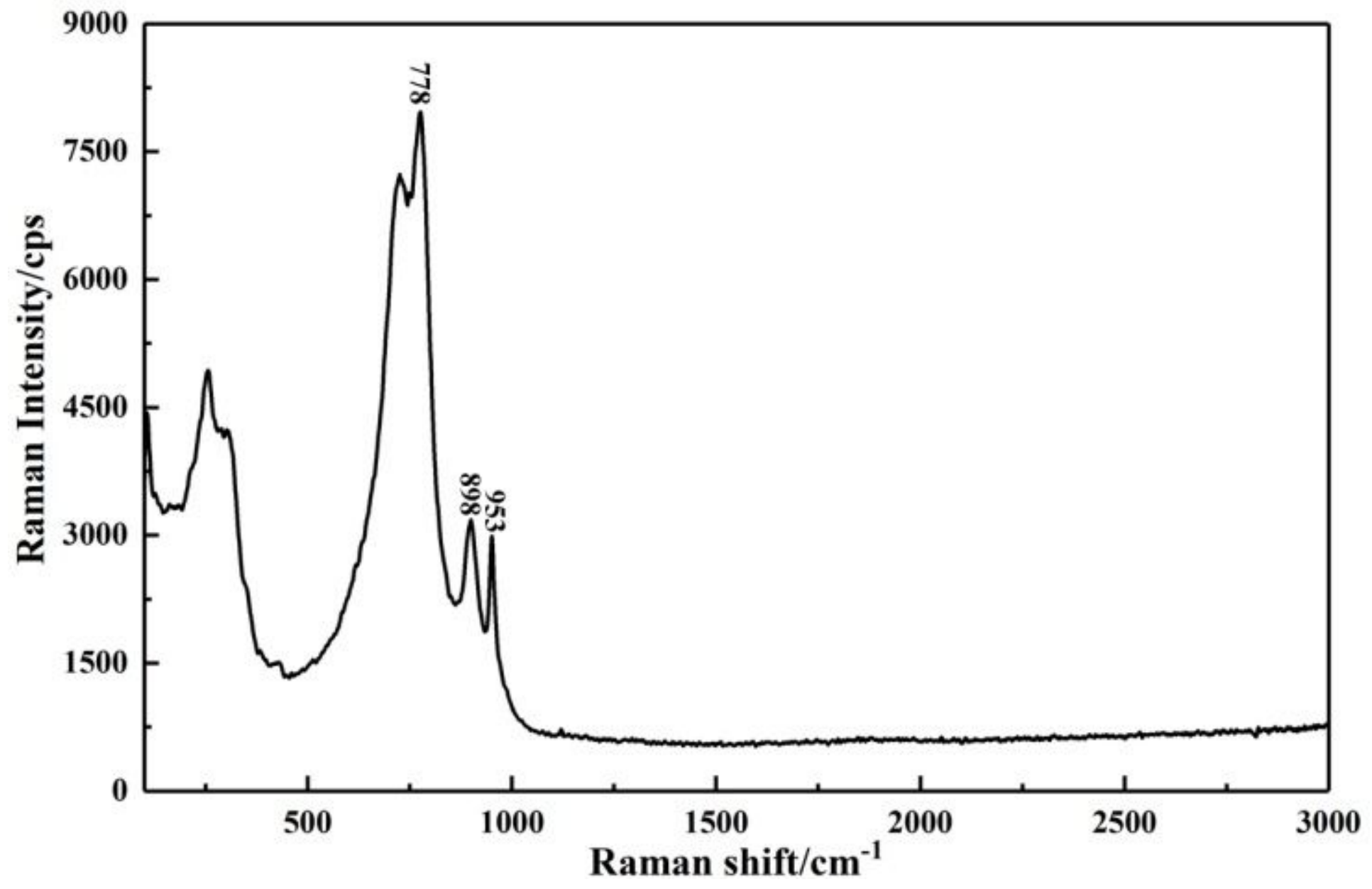

Figure 5

Raman spectrum of compound S1 


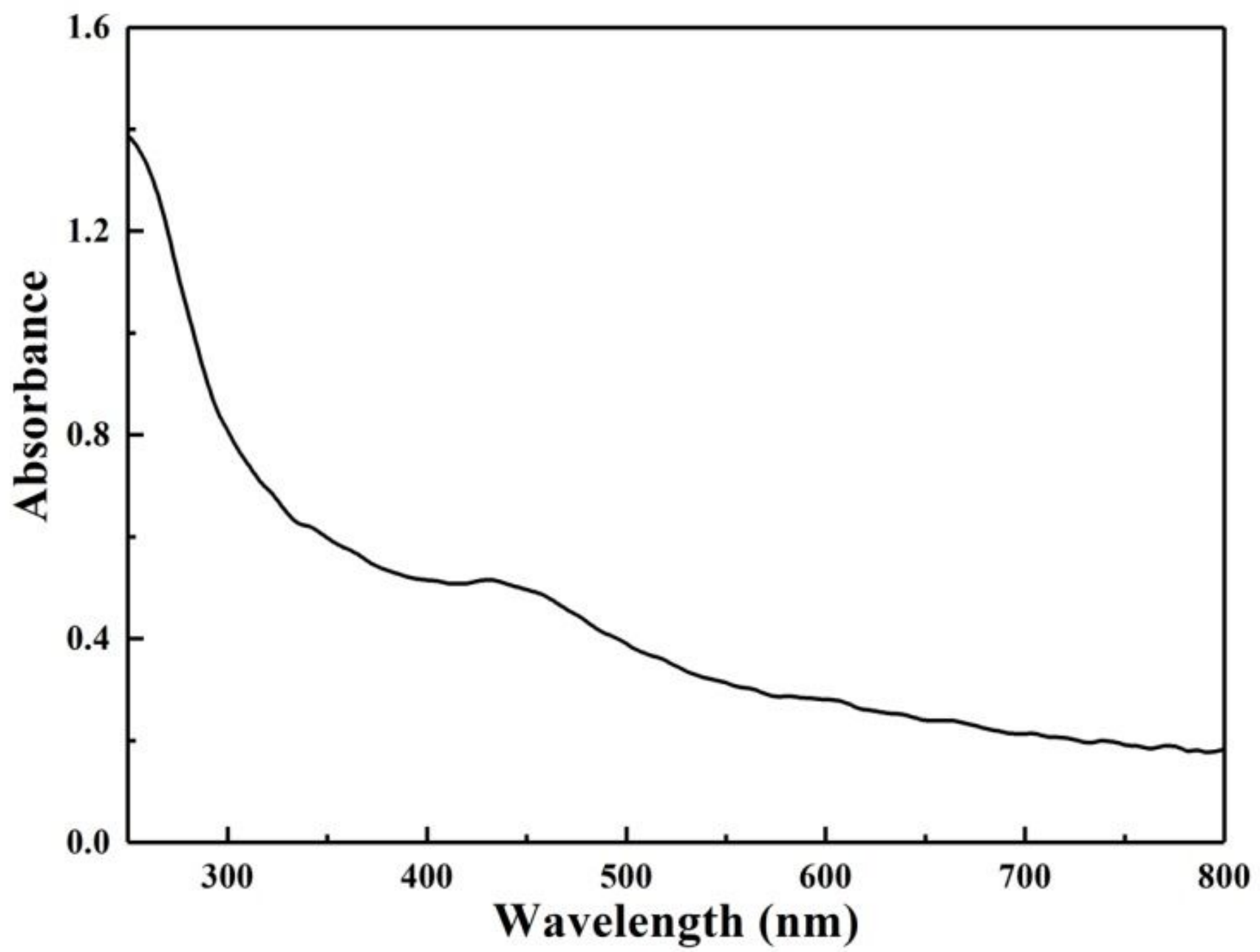

Figure 6

UV/Vis absorption spectrum of aqueous solution of compound S1

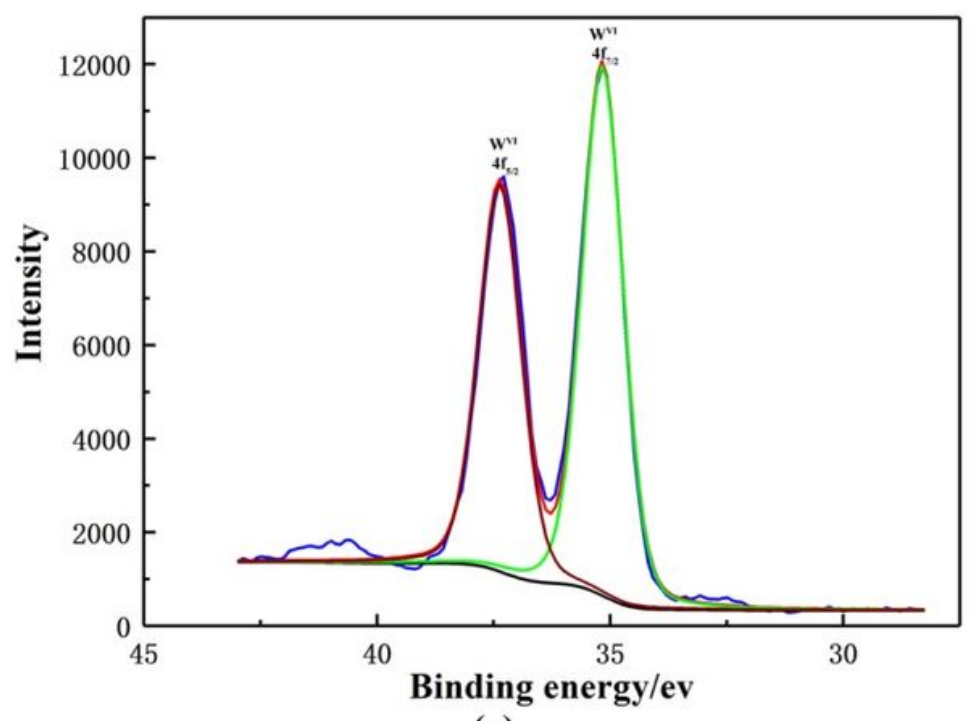

(a)

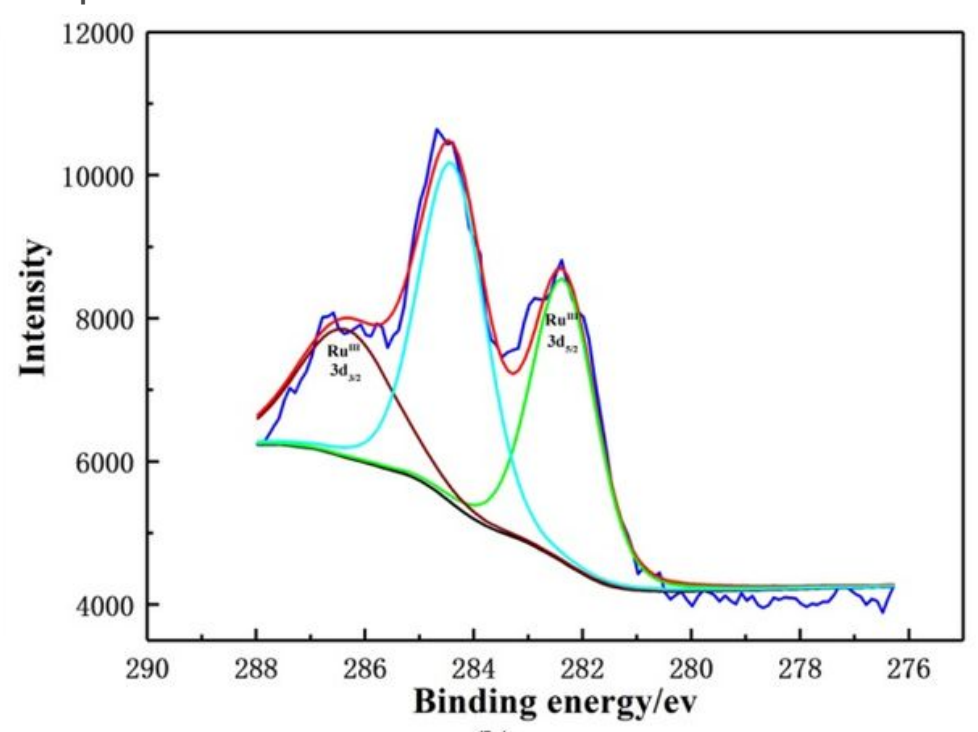

(b) 
Figure 7

The XPS spectra of (a) W4f and (b) Ru3d in compound S1
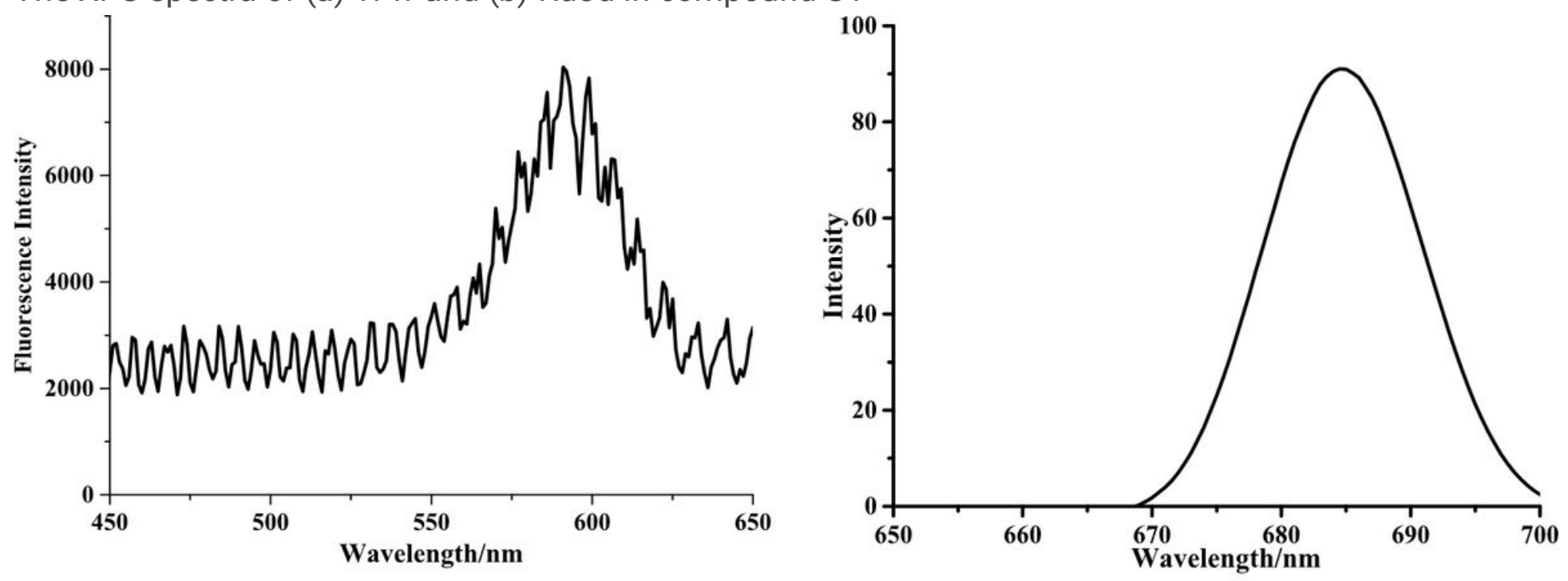

Figure 8

The fluorescence emission spectrum of the S1 (a) solid; (b) solution 


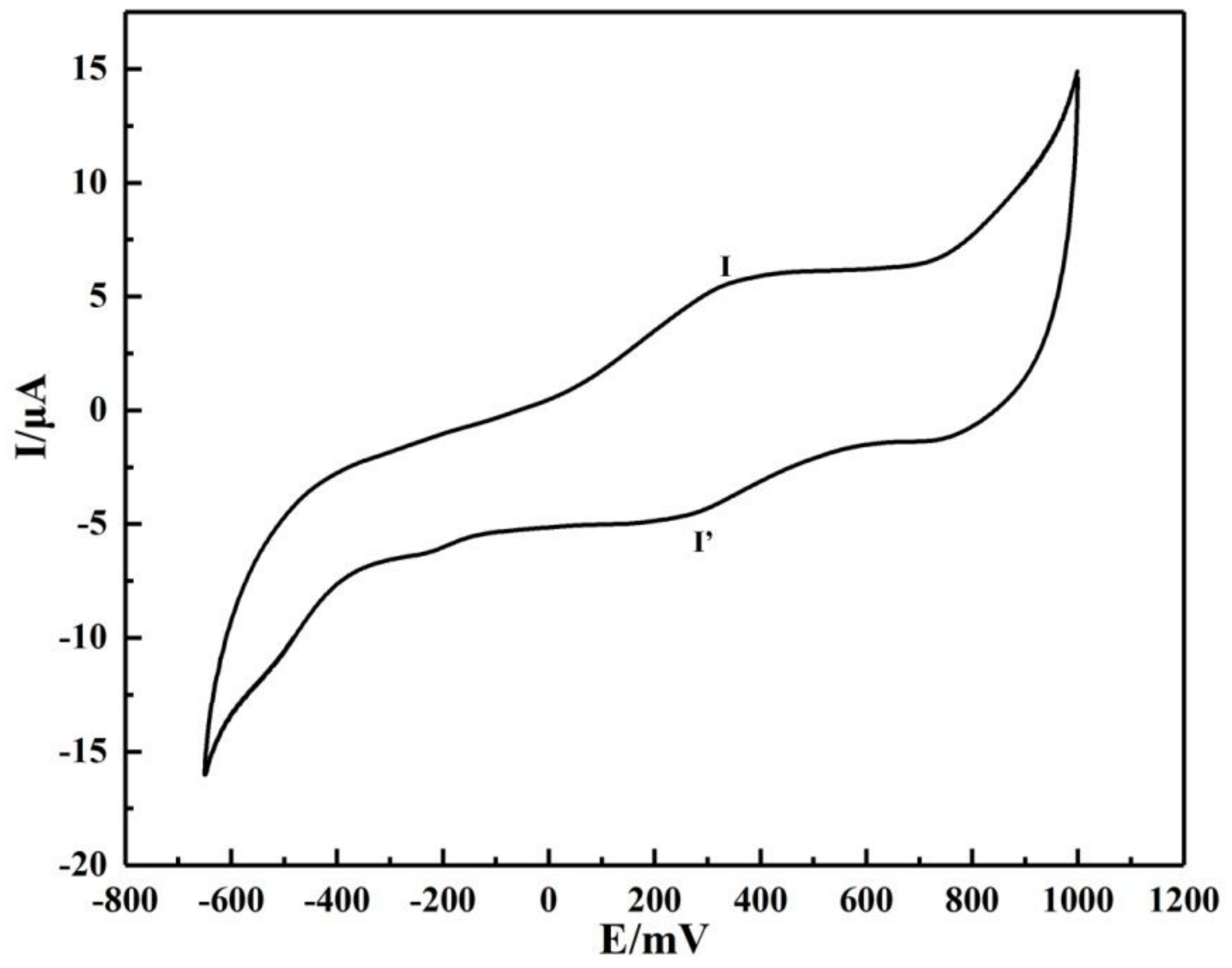

Figure 9

Cyclic voltammograms (scan rate $50 \mathrm{mV} / \mathrm{s}$ ) of complex $\mathrm{S} 1$ for $\mathrm{pH} 3$ in sulfate buffers. 

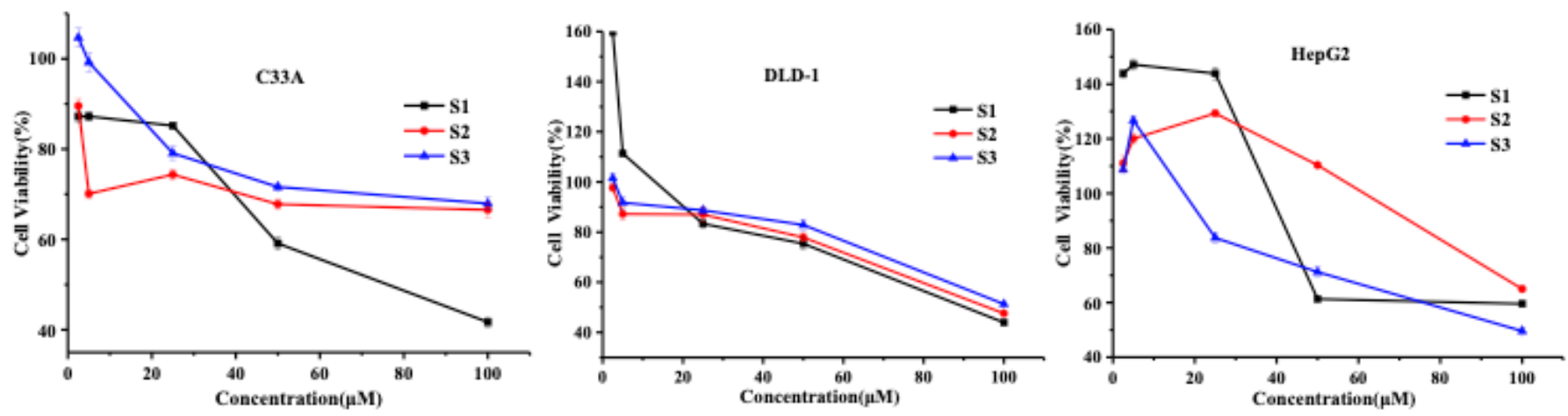

(a) $24 \mathrm{~h}$
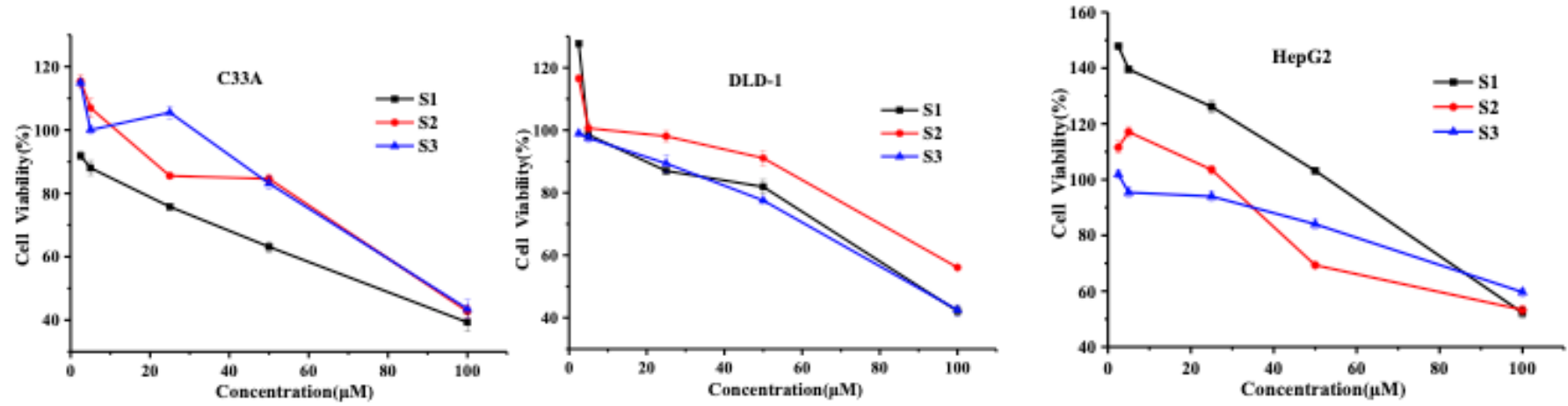

(b) $48 \mathrm{~h}$
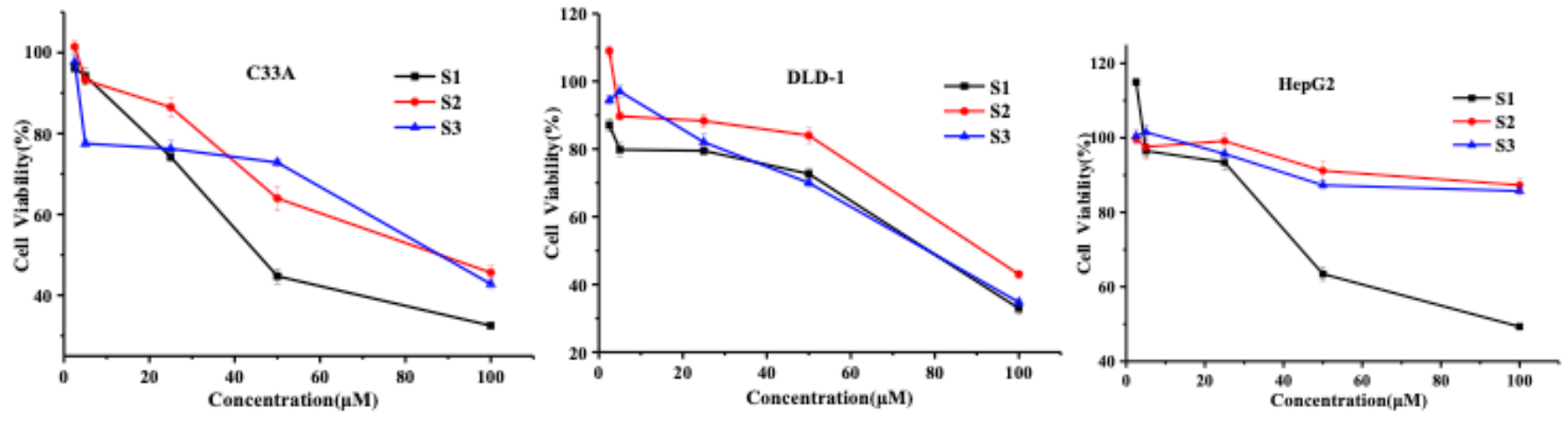

(c) $72 \mathrm{~h}$

\section{Figure 10}

Cell viability inhibition induced by S1-S3. (a) C33A, DLD-1 and HepG-2 cells were treated with S1, S2 and S3 for 24 h. (b) C33A, DLD-1 and HepG-2 cells were treated with S1, S2 and S3 for 48 h. (c) C33A, DLD-1 and HepG-2 cells were treated with S1, S2 and S3 for $72 \mathrm{~h}$. Cell viability was measured with the MTT assay. Data from three independent experiments run in triplicate cells were shown. 


\section{$\mathrm{S} 1(\mu \mathrm{M})$}

Control

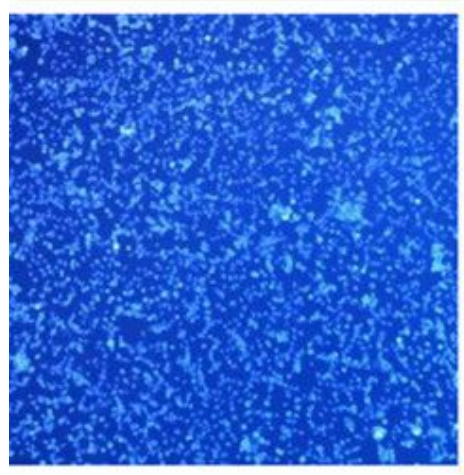

5

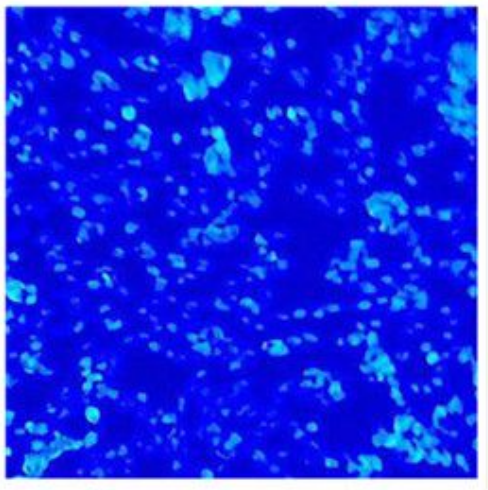

25

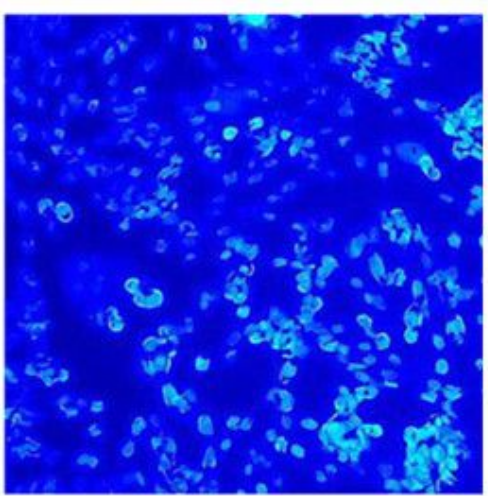

50

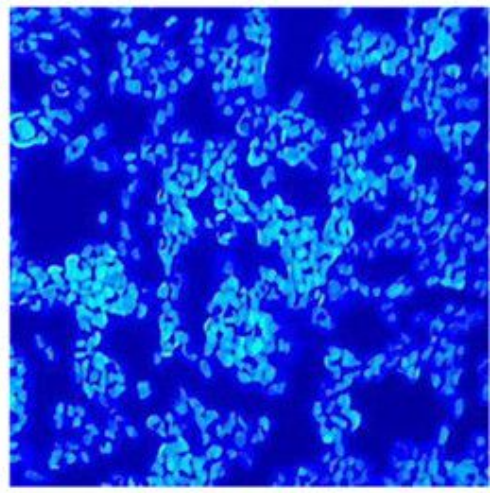

\section{Figure 11}

Hoechst 33342 staining of C33A cells $48 \mathrm{~h}$ 

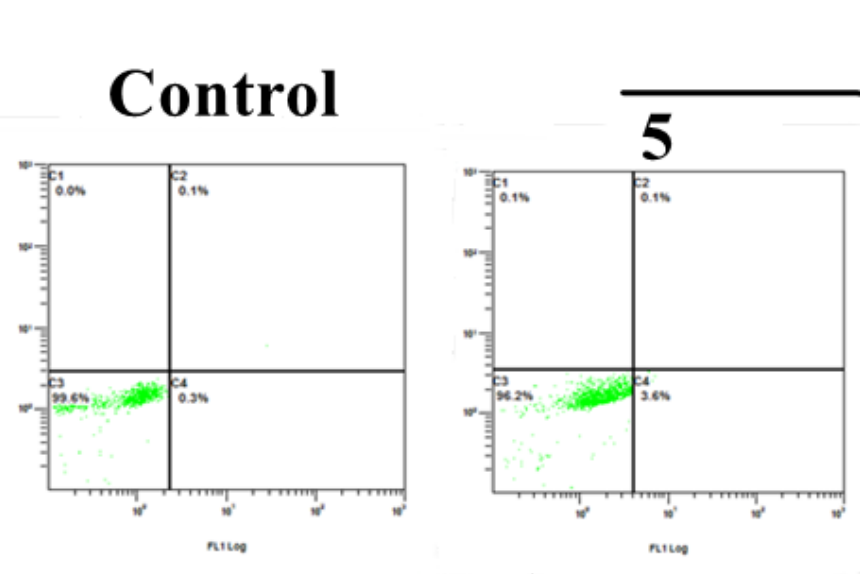

S1 $(\mu M)$

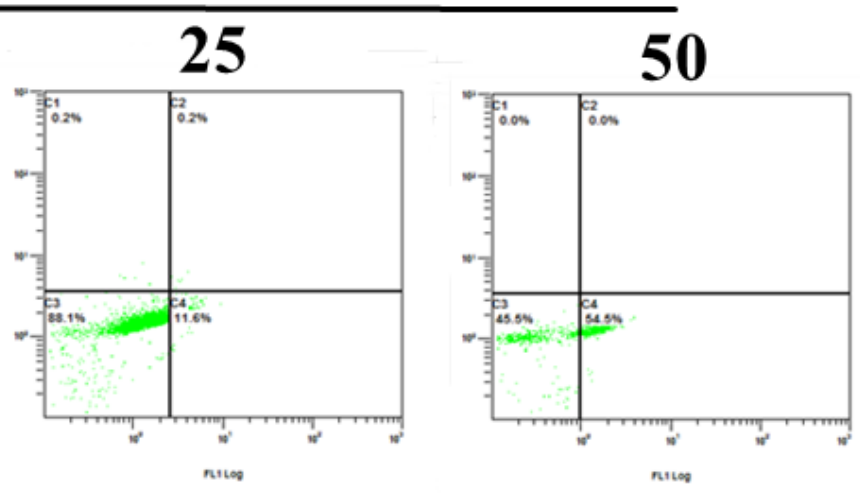

\section{Figure 12}

The percentage of living (B3), late apoptotic (B1), and early apoptotic (B4) C33A cells 


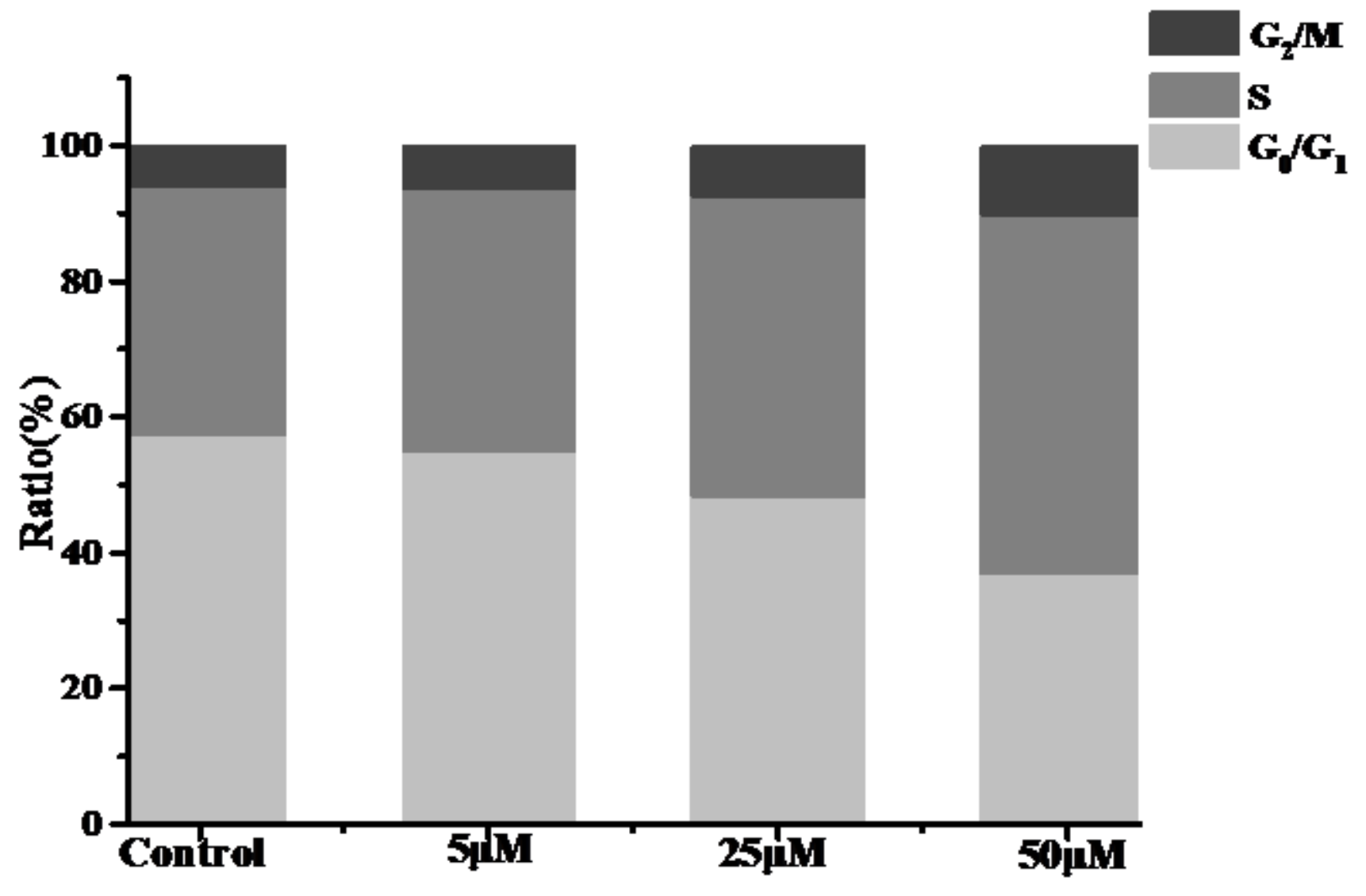

Figure 13

Cell cycle distribution on exposure of C33A cells to $5 \llbracket 25 \llbracket 50 \mu \mathrm{M} \mathrm{S1}$ complex 